\title{
Knowledge Management of Technology Development for Advocate
}

\author{
Budi Endarto \\ Faculty of Law, Wijaya Putra University \\ Arief Syahrul Alam \\ Faculty of Law, Wijaya Putra University \\ Suryo Atmojo \\ Faculty of Engineering, Wijaya Putra University
}

\begin{abstract}
This research was conducted with the support of Research And Community Service Directorate (Direktorat Riset dan Pengabdian Masyarakat), Deputy for Research and Development Reinforcement, Ministry of Research and Technology / National Research And Innovation Agency, Republic of Indonesia, through the Applied Research Grant, Fiscal Year of 2020.
\end{abstract}

\section{Abstract}

Advocate is a profession based on knowledge as a commodity which is exchanged for services and has economic value. Advocate as one of legal professions must continue to develop its professional abilities in a sustainable manner. However, in this digital era, besides of having knowledge about legal field, an advocate needs to cognize to the development of information technology. The information technology today has become the part of social life, including in judicial system process. This research uses a normative legal method with the statute and conceptual approach. This research aims to map the need for Knowledge Management Technology development that must be developed by an advocate as an effective and efficient legal delivery process. The result of this research indicates that to anticipate changes to demands for efficiency and encouragement of regulations related to the use of information technology in the judicial system of both private and public law, advocates must develop information technology as the basis for the legal process. The stages of development begin with the arrangement of Knowledge Management Systems by considering the Advocate's characteristics. From the framework of Knowledge Management System, Knowledge Management Technology can be developed to meet the needs of advocates in providing legal services based on information technology.

Keywords: Advocate, Knowledge Management Systems, Knowledge Management Technology.

DOI: $10.7176 / \mathrm{JLPG} / 102-02$

Publication date:October $31^{\text {st }} 2020$

\section{Introduction}

The use of information technology in legal practice is not a new thing. It can be seen in several countries which uses the term of new technologies on legal process. This means that information technology has become part of legal services. The developed information system has been implemented both in the court process and in evidentiary documents in the world of judiciary or electronic courts and electronic filling of court document. Apart from being used in the judiciary, the development of information system has also been developed and synchronized with other alternative dispute resolution. It can be seen from the study of The Law Society of Western Australia which explained: “... new technologies available include cloud computing, electronic document management systems, artificial intelligence, virtual law firms, online dispute resolution, electronic courts and electronic filling of court document, use of social media and bloskchain". ${ }^{1}$

Richard Susskind had predicted the change of perspective of advocates as legal profession for a long time, which he called new legal paradigm, specifically in the legal process. In which, there will be a shift in legal process "From print base to IT-Based Legal Systems". . This statement implies that "... legal practice and administration of justice will no longer be dominated by print and paper in tomorrow's legal paradigm. Instead, legal systems of the information society will evolve rapidly under the considerable influence of ever more powerful information technologies. ${ }^{3}$ Same thought also conveyed by Richard Volpato "... key challenge of survival for legal expertise will depend on service quality and a capacity to use data and technology tools". ${ }^{4}$ From those statements, there has been a paradigm shift in legal profession. To be able to remain competitive, it is not enough for an advocate to rely

\footnotetext{
${ }^{1}$ The Law Society of Western Australia, The Future of the Legal Profession, The Essential Membership for the Legal Profession, The Law Society of Western Australia, 2017, p.6.

${ }^{2}$ Richard, Susskind, The Future of Law, Facing the Challenges of Information Technology, Clarendon Press, Oxford University Press Inc, New York, 1996, p.41.

${ }^{3}$ Ibid, p.286-289

${ }^{4}$ Quoted from M. Ethan Katsh, Law in a Digital World, Oxford University Press Inc, New York, 1995, p.172.
} 
on legal expertise, but also must develop the strength of data and technology in delivering legal services.

The use of information technology as a tool of justice has also applied in Indonesia with the issuance of Supreme Court Regulation of the Republic of Indonesia No 1 of 2019 of Administration and Judge Case in an Electronic Courts (e-court) and Supreme Court Regulation of the Republic of Indonesia No 4 of 2020 of Administration and Criminal Case in an Electronic Court. With the application of an administrative court system based on information technology in Indonesia, therefore the information technology development model to meet the needs of advocate profession's practice is discussed more deeply.

\section{Discussion}

\subsection{Advocate's Characteristic as Legal Profession}

To understand the concept of profession, the terminology of profession itself must be traced. The term of profession in Black's Law Dictionary is formulated as “... A vocation or occupation requiring special, usually advanced, education, knowledge, and skill; law or medical professions. Also refers to whole body of such profession. The labor and skill involved in a profession is predominantly mental or intellectual, rather than physical or manual". ${ }^{1}$ From the terminology, it is clear that profession is a job which requires special expertise. Those expertise are required through education, knowledge, and skills such as legal profession or the medical profession. What distinguishes it from other work activities, the priority legal and medical profession lie in mental and intellectual abilities, compared to other jobs that rely in physical and manual abilities.

When referring to the early terminology of profession, Black's Law Dictionary stated that "the term originally contemplated only theology, law, and medicine, but as applications of science and learning are extended to other departments of affairs, other vocations also receive the name, which implies professed attainments in special knowledge as distinguished from mere skill". ${ }^{2}$ Which implies that there are several profession fields, i.e theology, law, and health as the starter of the professional development.

Richard L. Abel also conveyed the same thought of the origin of profession more explicitly "...The four "true" profession the Church, the army, medicine and law. ${ }^{3}$ According to Abel, basically, the origin of a profession was initially by four professions, i.e religion, related to church activities, the army, health, and law.

Along with economic development, during the pre-capitalism and capitalist profession known as "rise professionalism", a profession experienced a fundamental transformation both in terms of structure and ideology. ${ }^{4}$ This transformation began in the late $19^{\text {th }}$ century which was marked as the emergence of corporate capitalization or known as "connected with the rise of corporate capitalism". 5 The same though by Ignas Kleden regarding definition of a profession as a permanent job in a particular field which is performed skillfully based on knowledge master. By applying certain knowledge, someone can offer and provide high-quality services that have been scientifically tested, with the high pay according to the quality of the work and the results that have been offered. This view is more influenced by the capitalism society orders. ${ }^{6}$ Ignas Kleden sees a profession from a knowledge point of view as a commodity that is needed by market and is exchanged for services of high economic value. The economic value or stated as commercial value is a knowledge that depends on the quality which has scientifically tested.

Linear with Richard L. Able and Ignas Kleden, Richard Susskind stated that a profession is not only based on practice experience but more complex than that. A professional profession must have a combination of various aspects, including "the formal knowledge, know-how, experience and skill of professional". 7 This is asserted that a profession can be said as "knowledge business" or also known as "knowledge economy". "The use of those terms related to the advocate profession is still unclear and widely debated. However, generally, the use of "knowledge business" or "knowledge economy" - a profession constructs knowledge as a service commodity which is offered to the public. As Susskind stated that "professional practice is the "commoditization" of professional work." Therefore, advocates as one of the legal profession bearers, with knowledge that has economic value, have become commodities of legal services to the public or their clients. Related to this research, it is discussed how advocates prepare themselves so that the commodities offered can be delivered properly and efficiently to the clients, the keyword is the use of information technology. The use of information technology in legal services must also be planned through the development of architecture design and be arranged according to the structured stages.

\footnotetext{
${ }^{1}$ Bryan A. Garner, Black Law Dictionary, Seventh Edition, West Group St. Paul, Minn, 1999, p.1226.

${ }^{2}$ Ibid.

${ }^{3}$ Richard L. Able, The Rise of Professionalism, British of Law and Society, Vol.6 No, 1, Cardiff University, Summer, 1979, p. 83.

${ }^{4}$ Ibid

${ }^{5}$ Ibid

${ }^{6}$ Quoted from Bernard Arief Sidharta, Ethics and Legal Ethics Code, Varitas et Justitia, Vol 1, No.1, Journal Univeritas Parahyangan, 2015 , p. 222.

${ }^{7}$ Richard Susskind, Daniel Susskind, The Future of The Professions, How Technology Will Transform The Work Human Expert, Oxford

University Press, New York, 2015, p. 189.

${ }^{8}$ Ibid, p.193.

${ }^{9}$ Ibid, p. 195
} 


\subsection{The Policy of Information System Development in Judiciary}

The policy of the information system development in Indonesia contained in 2010-2035 Judicial Reform Blueprint which has issued by The Supreme Court of the Republic of Indonesia. In 2010-2035 of Judicial Reform Blueprint, it is explained the regulation for updating information technology through the development of information management which is aimed to ensure accountability, credibility, and transparency. As well as becoming a modern organization based on integrated information technology which is one of the important supports to Supreme Indonesian Judiciary Body. ${ }^{1}$ Therefore, the will of stakeholders in the Supreme Court and the judicial bodies under it places reforming information as one of the priority changes.

The arrangement of Judicial Reform Blueprint was motivated by the condition of the use of information technology in the judiciary, which is still running sporadically. Several initiatives of information technology development are still being performed partially and only to meet the needs of the work process. So far, the various systems developed are not connected to each other. The systems do not provide maximum benefit and there are gaps with the expected ideal architecture. To manifest an ideal architecture such as data \& information system, workflow management, document management, and facilities for extracting knowledge from the existing data sets (knowledge management), stages of information technology development are arranged in the environment of judicial bodies. ${ }^{2}$

The development of information technology within the Supreme Court and the judicial bodies under it is planned for 25 (twenty-five) years which is divided into 3 (three) stages:

a. Stage I, for the 5 (five) years, the goal is to optimize the existing information technology investments, data and information integration, and preparation and change of work culture to welcome the era of information technology;

b. Stage II, for the second 10 (ten) years, the goal is to create consistent information systems for all the judicial institutions to enable the use of data and information to maintain legal integrity, and also to open opportunities to access the court services;

c. Stage III, for the third 10 (ten) year, the goal is to integrate the judicial process with other stakeholders, including other law enforcers, in the framework of an integrated legal service system (integrated justice system). ${ }^{3}$

The integrated justice system, is an effort to achieve efficiency in financing as well as effectiveness in managing integrated information technology facilities, and also to provide information technology support for all the judicial organizations that will be furnished centrally.

All the organization units of Supreme Court and judicial bodies under them, will be furnished access to a single system which is managed centrally by Supreme Court through an integrated computer network in Indonesia. ${ }^{4}$

As a follow up to the 2010-2035 Judicial Reform Blueprint, The Supreme Court of the Republic of Indonesia has issued 2 (two) regulations, related to the administration and judicial system based on information technology. The first is Administration and Judge Case in an Electronic Courts or e-court. By applying e-court, the entire processes of the judiciary, starting from accepting lawsuit/petition, answers, replications, duplicates, conclusion, as well as managing and storing documents are using the electronic system. This administration and judge case which based on electronic will be applied to civil cases, civil religion, military and state administration.

The second is Supreme Court Regulation No 4 of 2020 of Administration and Criminal Case in an Electronic Court which is intended for handling criminal cases. Based on Article 2 of Supreme Court Regulation No 4 of 2020, in particular circumstances, The Judicial Panel, the Public Prosecutor, or the Defendant and their Advocates can request or determine to conduct a court electronically. By applying administration and judiciary electronically, it requires advocates to develop information technology that can support their profession. However, it also must be adjusted according to the characteristics of each advocate.

\subsection{Development of Knowledge Management Technology}

Ideally, information technology development should start from the planning stage of the architecture application of information system. Therefore, the first step is to build the architecture of the information system. This system is used as a reference to build a business model for legal services. Although there is no standard model business in legal service, there are several business models that can be applied which must be customized based on the needs and characteristics of each law office, as described by Bridgate Toy-Croin:

It is important to remember that no single model responds to all needs. Just as the current dominant model of hourly billing and full carriage of matters does not suite all clients needs, new business models will not be a

\footnotetext{
${ }^{1}$ The Supreme Court of the Republic of Indonesia, Judicial Reform Blueprint of 2010-2035, Supreme Court, 2010, p.61

${ }^{2}$ Ibid, p. 69.

${ }^{3}$ Ibid, p.69-70

${ }^{4}$ Ibid, p.65
} 
one-size fits all. ${ }^{I}$

The arrangement of comprehensive architecture design of information system can be developed by referring to Knowledge Management Systems. ${ }^{2}$ Within the system, there are several references that can be used for the arrangement of architectural designs as formulated by Deborah L. Edwards and Dirk E. Mahling. Edwards and Mahling arranged architecture design to develop information system which is divided in several categories or types, i.e administrative data, declarative knowledge, procedural knowledge, and analytical knowledge, as described below:

- Administrative data includes all of the nuts and bolts information about firm operations, such as hourly billing rates for lawyers, client names and matters, staff payroll data, and client invoice data;

- Declarative knowledge, is knowledge of the law, the legal principles contained in statutes, court opinions and other sources of primary legal authority, law students spend most of their law school careers acquiring this kind of knowledge;

- Procedural Knowledge, "procedural" is knowledge of the mechanics of complying with the law's requirements in a particular situation: what documents are necessary to transfer an asset from Company A to Company B, or what forms must be filed where to create a new corporation,

- Analytical knowledge is the conclusions reached about the course of action a particular client should follow in a particular situation. Analytical knowledge results from analyzing declarative knowledge (i.e. substantive law principles) as it applies to a particular fact setting. ${ }^{3}$

The arrangement of Knowledge Management Systems cannot be generalized to be applied by advocates. It must be customized to the characteristics and the needs of each advocate. Due to the characteristic differences of each advocate, the information system that is being developed by them is also different.

Based on Knowledge Management Systems that have been arranged, the next stage is to develop Knowledge Management Technology, which requires some stages as follow:

1. End-user tools are made available for knowledge workers. At the simplest stage, this means a capable networked PC on every desk or in every briefcase, withs standardized personal productivity tools.

2. Information about who knows what is made available to all people in the firm and to selected outside partners. The search engine should enable work with a thesaurus, since the terminology in which expertise is sought may not always match the terms the expert uses to classify that expertise;

3. Information from knowledge workers is stored and made available to all people in the firm and to selected outside partners;

4. Information systems solving-knowledge workers and solution seekers. Artificial intelligence is applied in these systems. ${ }^{4}$

Of those four stages, especially the development of information systems solving-knowledge workers and solution seekers which is based on artificial intelligence, it is expected to simplify the lawyers work in the digital era. Particularly, Indonesia adheres the civil law system, therefore the primary legal material is authoritative. ${ }^{5}$ The primary legal material consists of regulations, official records, or court decision. Meanwhile, the secondary legal material is law publications but it is not official documents. It includes textbooks, legal dictionaries, legal journals and comments on court decisions. ${ }^{6}$ This condition is totally different compared to the common law system countries, where the primary legal material is judicial decisions or jurisprudence.

As a matter of fact, the primary and secondary legal material in Indonesia has not well structured yet. Therefore, the classification process is needed by an advocate to ease the arrangement. Through the development of information systems solving-knowledge workers and solution seekers which is based on artificial intelligence, an advocate can perform inventory and classification of legal materials to provide more effective and efficient legal services.

\section{Conclusion}

The result of this research shows that advocate is a profession that involves knowledge as a service commodity that is being offered to the public. This knowledge becomes the professional work tool of "commoditization". In this era, the Supreme Court and the judicial bodies under it, has implemented administrative and judicial processes based on information technology. To respond to this condition, an advocate must begin to develop a model for

\footnotetext{
${ }^{1}$ Bridgate Toy-Cronin, John Billington QC, Matthew Smith and Kalyani Dixi, New Business Models For Legal Services, University of Otago, Legal Issue Center For The New Zealand Bar Association, 2016, p. 2

${ }^{2}$ Petter Gotstschak, Knowledge Management System : A Comparision of Law Firms and Consulting Firms, Informing Science, Volume 3 No. 3,2000, p. 116 .

${ }^{3}$ Deborah L. Edwards and Dirk E. Mahling, Toward Knowledge Management Systems in the Legal Domain. Proceedings of the International ACM SIGGROUP Conference on Supporting Group Work Group'97, USA:The Association of Computing Machinery ACm, 1997, p. 160.

${ }^{4}$ Petter Gotstschak, Toward a Model of Growth Stages fo Knowledge Management Technology in Law Firms, Informing Science, Volume 5 No. 2, 2002, p. 86-87.

${ }^{5}$ Peter Mahmud Marzuki, Legal Research, Kencana Prenada Media Group, Jakarta, 2005, p.181.

${ }^{6}$ Ibid., p.184-206
} 
legal services based on information technology. The first stage, an advocate starts to arrange the architecture design that refers to Knowledge Management Systems model, which is then used as the basis for developing Knowledge Management Technology.

\section{References}

Able, Richard L., 1979, The Rise of Professionalism, British of Law and Society, Vol.6 No, 1, Cardiff University. Edwards, Deborah L. and Dirk E. Mahling, 1997, Toward Knowledge Management Systems in the Legal Domain. Proceedings of the International ACM SIGGROUP Conference on Supporting Group Work Group'97, USA: The Association of Computing Machinery ACm.

Garner, Bryan A. 1999, Black Law Dictionary, Seventh Edition, West Group St. Paul, Minn.

Gotstschak, Petter 2000, Knowledge Management Systems: A Comparision of Law Firms and Consulting Firms, Informing Science, Volume 3 No. 3.

Gotstschak, Petter, 2002, Toward a Model of Growth Stages fo Knowledge Management Technology in Law Firms, Informing Science, Volume 5 No. 2,

Katsh, Ethan,1995, Law In Digital World, Oxford : Oxford University Press, New York.

Marzuki, Peter Mahmud, 2005, Legal Research, Kencana Prenada Media Group, Jakarta.

Sidharta, Bernard Arief, 2015, Ethichs and Legal Ethics Code, Varitas et Justitia, Vol 1, No.1, Journal Univeritas Parahyangan.

Susskind, Richard, 1996, The Furture of Law, Facing the Chalengges of Information Technology, Clarendon Press, Oxford University Press Inc, New York.

Susskind, Richard, Daniel Susskind, 2015, The Future of The Professions, How Technology Will Transform The Work Human Expert, Oxford University Press, New York.

Toy-Cronin, Bridgate John Billington QC, Matthew Smith and Kalyani Dixi, 2016, New Business Models For Legal Services, University of Otago, Legal Issue Center For The New Zealand Bar Association.

The Law Society of Western Australia, 2017, The Future of the Legal Profession, The Essential Membership for the Legal Profession, The Law Society of Western Australia.

The Supereme Court of the Republic of Indonesia, Judicial Reform Blueprint 2010-2035, Mahkamah Agung, 2010. The Supreme Court Regulation No 1 of 2019 on Administration and Judge Case in an Electronic Courts.

The Supreme Court Regulation No 4 of 2020 on Administration and Criminal Case in an Electronic Court, 